\title{
Influence of Value Addition to Agricultural Produce and Result Based Monitoring and Evaluation to Households Food Security in Murang'a County, Kenya
}

\author{
A. Ngugi, T. Maitho, and D. Kyalo
}

\begin{abstract}
Climate change is real and has created weather patterns that are not only complicated for metrological interpretation but also pose harm to agriculture and food production activities across the globe. The Results-Based Monitoring and Evaluation Systems helps in promoting good governance in research projects, strengthening accountability of household food resources utilization; facilitating transparency throughout project measurement; promoting understanding of Monitoring and Evaluation process amongst all stakeholders and enable effective utilization of value addition to food management throughout the food pipeline from produce to consumption activities and processes. Since agriculture is the backbone of food production in Kenya, food security is seriously threatened and as indicated in the recent cases of famine in Baringo and Turkana and parts of Central Kenya, it is clear that if not intercepted the situation may develop to a level that is unmanageable and thwart the existence of human beings. The stakeholders need several interventions' to successfully intervene in elevating the food situation, such as : a) Identify and map areas affected by famine in the region, b) Identify and adapt short term and drought resistant food crops, c) Introduce water fed modern irrigation farming methods to supplement on the rain reliance rain farming which is coupled unpredictable rainfall shortage in the region, d) To adopt greenhouse farming methods for weather sensitive crops e) Carry out intensive value addition to food produce in order to reduce post-harvest food loses throughout the food process. The result shows significant a positive significant effect moderating influence in model three $(R=0.836 a, R 2=0.699, F=577.639, P$-value $<0.05)$ which is strong and significant, suggesting a moderating effect in value addition on model three after an interaction term is introduced. The target group for the project are small scale farmers in the semi-arid areas of Murang'a County and the main activities will be the application of modern farming methods.
\end{abstract}

Index Terms - Evaluation for Households Food Security, Influence of Value Addition to Agricultural Produce, Result Based Monitoring.

\section{INTRODUCTION}

Value addition to agricultural produce is effected throughout the food pipeline post-harvest losses, value addition ensures that the small-scale household does not

Published on June 12, 2020

A. Ngugi, University of Nairobi, Kenya.

(e-mail: angugin@gmail.com)

T. Maitho, University of Nairobi, Kenya.

(e-mail: Tmaitho@uonbi.ac.ke)

D. Kyalo, University of Nairobi, Kenya.

(e-mail: ndunge.kyalo@gmail.com). suffer the biophysical losses, economic loss and nutrient losses. Value addition minimizes the causes of total food loss during harvesting, food storage, processing, packaging, marketing and consumption losses [12]. These processes provide longevity to food produce which is perishable by nature with very short shelf live. The ultimate promise is increased available food supply to households in Murang'a County. Result based monitoring and evaluation is purposefully utilized in tracking these implementation processes from input, activities, output, outcome to impact and systematically measuring the effectiveness of the programmes [2]. It helps determine exactly when a programme is on track and when changes may be needed. Result Based Monitoring and evaluation is a useful tool of ensuring that goals and objectives of a project are applied for the ultimate high degree success of the programme as envisioned [15].

The Kenya Government on Vision 2030 aims at achieving national food security as one of the key objectives in agricultural sector [13]. Agricultural sector is the mainstay of the Kenya's economy and the sector directly contributes $24 \%$ of the Gross Domestic Product (GDP). (Kenya Food Security Steering Group, 2008), explains that the current food insecurity problems are attributed to several factors, including the frequent droughts in most parts of the country, high costs of domestic food production due to high costs of inputs in seeds and fertilizer especially, displacement of a large number of farmers in the high potential agricultural areas during the post-election violence in early 2008. Global food prices and low purchasing power for large proportion of the population due to high level of poverty. Kenya Comprehensive Food Security and Vulnerability Survey (CFSVA) provided for the first 47-county overview of food security and nutrition in Kenya since the process of devolution began in 2013, shows data and analysis for the report drawn from 2014, Kenya Demographic and Health Survey (KDHS), World Food program (2016). Reference [14] shows initiatives which food per person is one of the current problems facing food production and strategy in improving food security, the food index score verification of Murang'a County (2009 censers) verses other Counties in Kenya has been viewed by FAO and KFP. The report shows that Murang'a County has a total Population of 942,581 people and falls in the ASAIL region with prevalence of households with poor and borderline food consumption score of $35 \%$ or less). 


\section{Statement Of The PRoblem}

Since climate is tremendously changing globally, Kenya seems to be facing more consequences because agriculture which supports higher portion of the GDP is submerged with this harshness. In addition to the traditional methods of rain fed farming that are no longer effective, and our agricultural yields are on great decline. The Government of Kenya has been compelled to import severally various food commodities to bridge food need, such as maize, rice, beans, and sugar among others from other countries such as Mexico, China, Brazil, South Africa among others. The consistency of the harsh weather is slowly making Kenya to over rely on imports which apart from draining our economy through imbalance of trade also carry health hazards since some of the products imported are alleged to have failed basic standards in international markets. The specification has exhibited toxic substances as their contents such as mercury in sugar from Brazil, aflatoxins in maize from South Africa and Mexico. People have developed different ailments from consumption of foreign substances in food, cancer is highly on the rise and is alleged to be spearheaded by such foreign substances in food that people consume.

The Kenya intermittent weather has every now and then had timely rainfall whereby farmers have enjoyed high bumper yields in food commodities. However, due to lack of value addition in food produce, post-harvest losses are too high, a high percentage of the yield goes to waste. Systems of value addition that would go a long way in ensuring that farmers have enough food throughout the year from that one bumper harvest to the next harvest season are lacking in proper implementation and effectiveness. From a professional angle it is not fair to stake both our money to buy food commodities from abroad using hard earned foreign exchange and at the same time stake our lives in consuming the same while we can develop safe alternatives from our own farming.

\section{LITERATURE REVIEW}

Historically, value addition to agricultural produce goes back, thousands of years, whereby humans used methods of value addition by food preservation, in order for them to stock food for later consumption [7]. Long before invention of standup freezers, refrigerators, ice boxes, tinned fish, bagged bread, canned soup and provision outlets appeared in scenario, indigenous preservation ways was already been figured ways to preserve foods, humans in their wily had already discovered way of adding food longevity, and still resourceful humans can still do so, if given a chance would still diverse many satisfying ways of traditional food preparation and indigenous preservation methods as practiced all years and handed down to younger generations over the years [8]. Value addition to food produce helps in reduction of food spoilage throughout the food pipeline from produce to consumption, through benefiting methods such as processing, packaging, marketing and consumption for ultimate food security. The various methods of value addition in food preservation that households engage in their homestead level are essential, be it modern food preservation using deep freezers or the traditional local remedy of ashes or charcoal, sun drying and storage in local barns goes a long way in attaining some form of food security [3]. Food security is a situation associated with the supply of food, and people' access to food. The idea of food security has additionally been deeply enriched by using scholarly work on human rights, sustainable livelihoods, women's worries and gender problems in development, food quality and safety, natural agriculture and sustainable environments [9]. Food security encompasses the Enhanced Dietary Diversity Scale quality and nutritious food intake, enough quantity at intake for adults' and children in a day [4]. Measurement of Household Hunger Scale (HHS) on farmers' household checks if there is ever a time, they have no food to eat in household due to lack of resources; or any household members go to sleep at night hungry because there was not enough food. Household Food Access Scale was achieved when Food security was first added to the worldwide community at the arena in food convention prepared via the United States general assembly in 1974 [14]. This work transformed intra-family level knowledge of food distribution that takes into account households and gender equality, the surroundings, and human aspirations and dignity. The issues over meals safety have existed throughout records.

\section{RESEARCH METHOdOLOGY}

Researcher adopted a descriptive survey design for the investigation which is most appropriate for this type of study. Research approach falls into two major data collection methods of quantitative and qualitative methods. The study targeted 134,654 heads of households, 20 local leaders such as chiefs and sub-chiefs, and 14 Agricultural Extension Officers from the 3 constituencies with 18 wards. The sample size calculation for this study assumed $95 \%$ confidence level and 5\% precision. The study population for livestock and Agricultural Extension Officers' censors was carried out on stratum as the population was too low to warrant sampling. The researcher used two types of instruments namely questionnaire and interviews guide. Interview guide was used in order to collect data from Local Leaders and Agricultural Extension Officers, both were expected to be knowledgeable to provide answers from a point of knowledge. The questionnaire was used in order to collect data from heads of households; the questionnaire was able to clarify questions due to the diverse education levels of households ranging from semi illiterate to highly educated people.

Data analysis took place at two levels - descriptive statistics level and inferential statistics level. Descriptive analysis aims at summarizing distributions and describing a set of data on variables of the study. This analysis was used to profile respondents. It was carried out by producing percentages, means and standard deviation and results were displayed in tables. Simple and multiple linear regressions were used to test the hypothesis. The Pearson correlation coefficient was used to determine the strength or degree of a relationship between the independent variable and the dependent variable. All the statistical tests were conducted at 95 percent confidence level. P-value was used to ascertain the significance of each construct in the regression model 
The variables were taken to be statistically significant if the $\mathrm{p}$-value $\leq 0.05$.

\section{RESEARCH FINDINGS AND DISCUSSIONS}

The study targeted 382 respondents; however, the researcher received response from 326 respondents. Further scrutiny established that six questionnaires were poorly filled and hence excluded from analysis. The effective sample dropped to 320 respondents forming $83.77 \%$ response rate, which was considered adequate for analysis. This study adopted a cut off Cronbach value of 0.7 which is considered a strong measure of reliability consistency [6]. This was confirmation of reliability of the data used to draw conclusions from theoretical concepts.

\section{A. Test of Hypotheses}

Hypothesis was formed on the basis of the research objective; it was tested using simple regression analysis. The hypotheses were tested at 95 percent confidence level $(\alpha=0.05)$, hence decision points to reject or fail to reject a hypothesis were based on the p-values. Where $p<0.05$, the study failed to reject the hypotheses, and where $p>0.05$, the study rejected the hypotheses. Interpretations of results and subsequent discussions also considered correlations (R), coefficients of determinations (R2), F-Statistic values (F) and beta values $(\beta)$. R2 indicated the change in dependent variable explained by change in the independent variables combined. Further, the higher the F-Statistic, the more significant the model. The negative or positive effect of the independent variable on the dependent (either negative or positive) was explained by checking the beta $(\beta)$ sign. The $\mathrm{R}$-value shows the strength of the relationship between the variables, t-values represent the significance of individual variables. The findings are presented along study objectives and corresponding hypotheses.

The hypothesis formulated was that; H1 Moderating influence in Value addition to Agricultural produce, has significance influence between Result Based Monitoring and Evaluation and households' food security in the County of Murang'a.

Table 1. The Moderation Results of Value addition on Result Based Monitoring and Evaluation and Households' Food SeCuRity

\begin{tabular}{|c|c|c|c|c|c|c|c|c|c|c|}
\hline \multicolumn{11}{|c|}{ Model Summary } \\
\hline & \multirow[b]{2}{*}{ Model } & \multirow[b]{2}{*}{$\mathrm{R}$} & \multirow[b]{2}{*}{$\begin{array}{c}\mathrm{R} \\
\text { Square }\end{array}$} & \multirow[b]{2}{*}{$\begin{array}{l}\text { Adjusted } \\
\text { R Square }\end{array}$} & \multirow[b]{2}{*}{$\begin{array}{l}\text { Std. } \\
\text { Error of } \\
\text { the } \\
\text { Estimate }\end{array}$} & \multicolumn{4}{|c|}{ Change Statistics } & \multirow[b]{2}{*}{$\begin{array}{l}\text { Sig.F } \\
\text { Change }\end{array}$} \\
\hline & & & & & & $\begin{array}{l}\text { R Square } \\
\text { Change }\end{array}$ & $\begin{array}{c}\mathrm{F} \\
\text { Change }\end{array}$ & df1 & df 2 & \\
\hline 1 & $\begin{array}{c}\text { Result based monitoring } \\
\text { and evaluation }\end{array}$ & $0.371^{\mathrm{a}}$ & 0.138 & 0.136 & 0.68709 & 0.138 & 79.586 & 1 & 499 & 0.000 \\
\hline 2 & $\begin{array}{c}\text { Result based monitoring } \\
\text { and evaluation, value } \\
\text { addition }\end{array}$ & $0.427^{\mathrm{a}}$ & 0.182 & 0.180 & 0.76920 & 0.182 & 111.006 & 1 & 499 & 0.000 \\
\hline 3 & $\begin{array}{l}\text { Result based monitoring } \\
\text { and evaluation, value } \\
\text { addition interaction }\end{array}$ & $0.836^{\mathrm{a}}$ & 0.699 & 0.698 & 0.30150 & 0.699 & 577.639 & 2 & 498 & 0.000 \\
\hline
\end{tabular}

a. Predators; (constant) Result based Monitoring and Evaluation process.

ANOVA

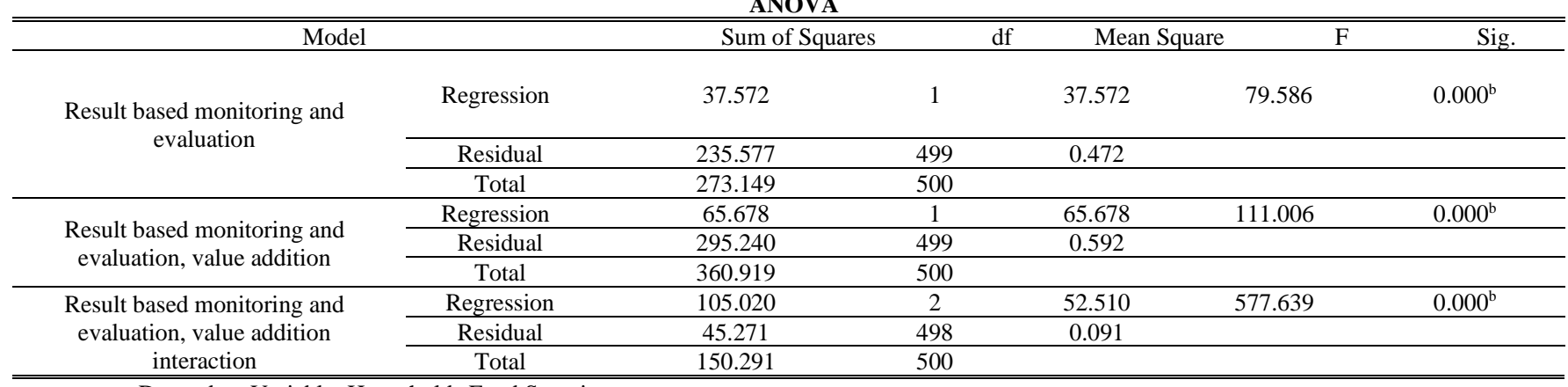

a. Dependent Variable; Households Food Security.

b. Predictors: (Constant) Result Based Monitoring and Evaluation, Value Addition

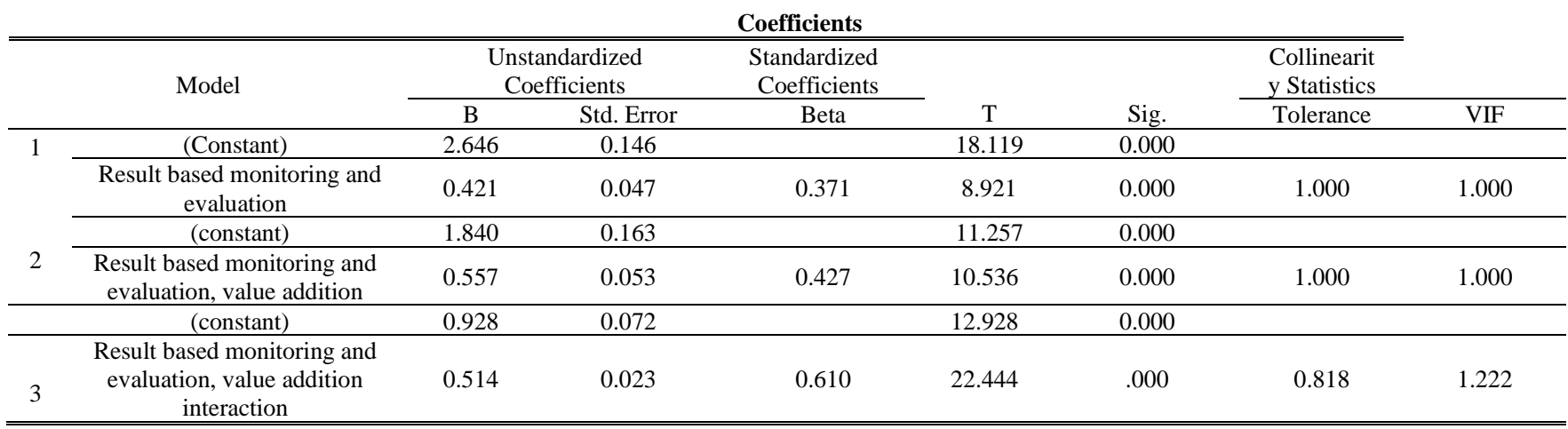

a. Dependent variable; Households food security 
The result in Table.1 on the moderating effect of value addition on the connection amongst Result Based Monitoring and Evaluation and food security in the household was computed using three steps. In model one the result shows that the association between Result Based Monitoring and Evaluation and households food security was moderate and significant $(\mathrm{R}=.371 \mathrm{a}, \mathrm{R} 2=0.138$, $\mathrm{F}=79.586$, $\mathrm{P}$-value $<0.05)$. In model two $(\mathrm{R}=0.427 \mathrm{a}$, $\mathrm{R} 2=182, \mathrm{~F}=111.006, \mathrm{P}$-value $<0.05)$ which was moderate and significant and in model three $(\mathrm{R}=0.836 \mathrm{a}, \mathrm{R} 2=0.699$, $\mathrm{F}=577.639$, $\mathrm{P}$-value $<0.05$ ) which is strong and significant, suggesting a moderating effect in model three after an interaction term is introduced. The value of the interaction term $(\mathrm{RBME} * \mathrm{Va})$ had a significant influence $(\beta=0.514$, $\mathrm{t}=22.444, \mathrm{P}<0.05)$ thus confirming a moderation effect of value addition therefore supports the hypothesis that value addition possesses an essential moderating effect on the interrelation among Result Based Monitoring and Evaluation and household's food security.

\section{CONCLUSION AND RECOMMENDATIONS}

Based on the Moderating Influence in Value addition to Agricultural produce, it was established that there is significance influence between moderation effect of value addition and Coefficient of determination and essential moderating effect on the interrelation among Result Based Monitoring and Evaluation and household's food security. On the moderating effect of value addition on the connection amongst Result Based Monitoring and Evaluation and food security in the household was computed using three steps. In model one the result shows that the association between Result Based Monitoring and Evaluation and households food security was moderate and significant. The study further established this relationship was also found to be significant and depicts that Result Based Monitoring and Evaluation is crucial in determining households' food security. Testing the moderating effect of Value addition on the link amongst Result Based Monitoring and Evaluation and households' food security showed the results being strong and significant, suggesting a moderating effect in model three after an interaction term was introduced.

This study presents recommendations derived from the findings and practice of result-based monitoring and evaluation mechanism and its application on value addition to agricultural produce for food security. The recommendations have significant implications on the theory, researchers, M\&E practitioners, civil society organizations, policy and government as contained in this part of the study. In consideration that the Government of Kenya and other non-governmental organizations are moving towards implementation of various aspects of household food security including result-based monitoring and evaluation processes among others, this study has impact to the government, enacting organs and society.

\section{REFERENCES}

[1] J. Alston, "Spillovers," Australian Journal of Agricultural and Resource Economics, vol. 46, no. 3, pp. 315-346, 2000.

[2] M. Bamberger, H. White, "Using strong evaluation designs in developing countries: Experience and challenges," Journal of MultiDisciplinary Evaluation, vol. 4, no. 8, pp. 58-73, 2007.

[3] D. Bryceson, C. Kay, Disappearing peasantries? Rural labor in Africa, Asia and Latin America. London: Intermediate Technology Publications, 2000.

[4] F. Burchi, "Child nutrition in Mozambique in 2003: the role of mother's schooling and nutrition knowledge," Economics and Human Biology, vol. 8, no. 3, pp. 331-345, 2010.

[5] W. Cline, Global warming and agriculture: Impact estimates by country, Washington: Peterson Institute, 2007.

[6] J. Creswell, Research design: Qualitative, quantitative and mixed methods approaches, 3rd Ed., Los Angeles: Sage Publications, Inc., 2009.

[7] D. Madison, Preserving food without freezing, Chelsea: Chelsea Green Publishers, 2007.

[8] F. Ellis, Rural Livelihoods and Diversity in Developing Countries, Oxford: Oxford University Press, 2000.

[9] FAO. (2012). The state of food and agriculture. FAO, United Nations Rome. [Online]. Available: http://www.fao.org/catalog/inter-e.htm

[10] FAO, Agricultural and Development Economics Division, Food Security, 2016.

[11] FAO, The Role of Women in the Conservation of genetic Resource of Maize. Fats and oils in human nutrition. Report of a Joint FAO/WHO Expert Consultation. Rome, Food and Agriculture Organization (FAO Food and Nutrition paper No 57), 2002.

[12] T. Joris, C. Jeroen, Reducing food wastage, improving food security, Food \& Business Knowledge Platform Bezuidenhoutseweg, The Hague, The Netherlands, 2014.

[13] Kenya vision 2030. Food security. [Online]. Available: http://www.foodsecurityportal.org/

[14] R. Max, R Hannah, Food per Person, The State of Food Insecurity in the World: The World Food Programme, 2017.

[15] C. Ray, Ten steps to a results-based monitoring and evaluation system, Washington, 2004.

[16] D. Russell, Accountability. In Succeeding in the project management jungle: How to manage the people side of projects, New York, NY: AMACOM, 2011.

[17] P. Stratford, "Reliability: Consistency or differentiating among subjects? Physical therapy," Journal of the American Physical Therapy Association, vol. 69, pp. 299-300, 1989.

A. Ngugi is part-time lecturer and $\mathrm{PhD}$ student at the Department of Extra Mural, School of Open Distance and Learning. University of Nairobi. P.O Box 30197-00100. Cell phone +245722717066. Email angugin@gmail.com.

T. Maitho is lecturer at the Department of Public Health, Pharmacology and Toxicology. University of Nairobi. P. O Box 30197-00100. Cell phone+245721301010. Email Tmaitho@uonbi.ac.ke

D. Kyalo is lecturer, Department of Extra Mural, School of Open Distance and Learning. University of Nairobi. P.O Box 30197-00100. Cell phone+254722821341. Email ndunge.kyalo@gmail.com 